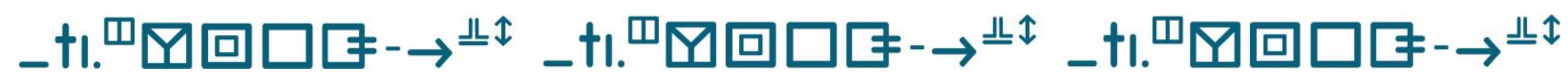

\section{Métodos de ensino e avaliação da aprendizagem de surdos no Ensino Médio: o que dizem os profissionais de Libras-Português?}

\section{Teaching methods and assessment of learing of the deaf in High School: what do Libras-Portuguese professionals say?}

iD Edivaldo dos Santos Júnior

Instituto Federal de Educação, Ciência e Tecnologia de Tocantins, Palmas,

Tocantins, Brasil

junior.antropos@gmail.com

iD 9 Rivadavia Porto Cavalacante

Instituto Federal de Educação, Ciência e Tecnologia de Tocantins, Palmas,

Tocantins, Brasil

riva@ifto.edu.br

iD (9) Weimar Silva Castilho

Instituto Federal de Educação, Ciência e Tecnologia de Tocantins, Palmas,

Tocantins, Brasil

weimar@ifto.edu.br

iD 9

Mary Lúcia Gomes Silveira de Senna

Instituto Federal de Educação, Ciência e Tecnologia de Tocantins, Palmas, Tocantins, Brasil

marysenna@ifto.edu.br

iD 9

Jair José Maldaner

Instituto Federal de Educação, Ciência e Tecnologia de Tocantins, Palmas, Tocantins, Brasil

jair@ifto.edu.br

Resumo: Este artigo tem como objetivo investigar e discutir questões relacionadas à adequação dos métodos de ensino e avaliação dos saberes de linguagem na educação de surdos em contexto de aulas regulares do Ensino Médio público. Para tanto, buscou-se fundamentação na Teoria histórico- 
cultural de Lev Vygotsky, que subsidia a compreensão do papel da linguagem no desenvolvimento humano, e nos aportes de Yves Chevallard e Paulo Freire, sobre as transformações adaptativas dos saberes escolares a serem ensinados e aprendidos no processo educacional, estabelecendo diálogo destes com pesquisadores da área da educação de surdos. O trabalho contou com o método qualitativo, mediante pesquisa exploratória de fontes teóricas, análise documental e de relatos de experiências de três profissionais de Libras-Português, atuantes na educação pública do Tocantins. O resultado da pesquisa revela inadequação dos métodos de ensino e avaliativos, nos quais língua e cultura do surdo são menosprezadas, prevalecendo apenas o método de leitura de texto em português.

Palavras-chave: Saberes de linguagem. Adequação metodológica. Educação de surdos. Ensino e Avaliação.

Abstract: This article aims to investigate and discuss issues related to the adequacy of teaching methods and language knowledge assessment in deaf education in the context of regular high school classes. To this end, we sought support on Lev Vygotsky' historical-cultural theory that supports the understanding of language role in human development, Yves Chevallard and Paulo Freire contributions on the adaptive transformations of school knowledge to be taught and learned in the educational process. establishing dialogue with deaf education researchers The work included a qualitative method through exploratory research of theoretical sources, documental analysis and experience reports of three Professionals of Libras-Portuguese working in public education in Tocantins. Results reveal the inadequacy of 
teaching and evaluation methods in which deaf language and culture are underestimated, with only the text-reading method in Portuguese prevailing.

Keywords: Language knowledge. Methodological adequacy. Deaf education. Teaching and Assessment.

Submetido em 13 de agosto de 2020.

Aceito em 26 de maio de 2021.

Publicado em 19 de novembro de 2021. 


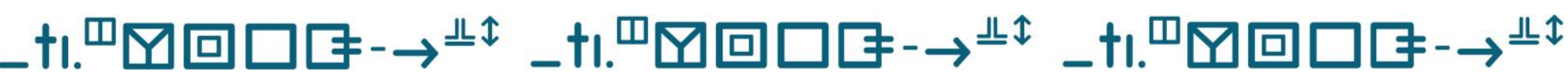

Métodos de ensino e avaliação da aprendizagem de surdos no Ensino Médio: o que dizem os profissionais de Libras-Português?

Edivaldo dos Santos Júnior • Rivadavia Porto Cavalcante et al.

\section{Introdução}

No contexto brasileiro de educação formal para a pessoa surda, os procedimentos de ensino e aprendizagem voltados para este público estudantil, de forma que atenda suas reais necessidades, ainda se configuram como desafios para os educadores. Isso acontece, principalmente, no que concerne à construção de suportes metodológicos que priorizem as especificidades do ensino e aprendizagem das linguagens necessárias para o desenvolvimento intelectual daquele público estudantil. De igual modo que auxiliem, de facto, a concretização dos objetivos das políticas públicas voltados para a inclusão social desses alunos.

A respeito do exposto, a educação brasileira conta com um repertório de leis que visa garantir o direito e inclusão escolar do surdo. No entanto, pesquisas recentes (MALLMANN et. al, 2014; SKLIAR, 2017; SILVA, 2018) revelam descompasso entre as proposições dos documentos legais com o que temos em termos de resultado do ensino e da aprendizagem no contexto da formação básica desses sujeitos. Senão, vejamos:

todos os atores sociais envolvidos na inclusão dos sujeitos surdos, inclusive eles mesmos, vivem dificuldades para, de fato, estabelecer uma inclusão real. [...] os surdos enfrentam barreiras na comunicação [...] dificuldades no processo ensino e aprendizagem para tornarem-se alfabetizados e letrados, discriminação dos colegas de sala de aula. Os professores sentem e relatam uma dificuldade no sistema educacional que acaba por não oferecer formação adequada e continuada. E os intérpretes formam um grupo que ainda estão constituindo a identidade profissional, buscando compreender seus espaços e favorecer o acesso às experiências escolares aos surdos (MALLMANN et. al, 2014, p. 34). 


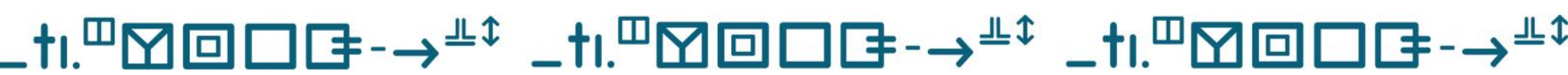

Métodos de ensino e avaliação da aprendizagem de surdos no Ensino Médio: o que dizem os profissionais de Libras-Português?

Edivaldo dos Santos Júnior • Rivadavia Porto Cavalcante et al.

Conforme indicado no excerto em tela, o enfrentamento do aluno surdo, em face de suas dificuldades no processo de letramento ${ }^{1}$ e os impasses de professores desprovidos de suporte metodológico na condução das ações formativas, coloca em questão o funcionamento das políticas públicas inclusivas destinadas à população surda. Não se pode perder de vista que a concretização dos direitos adquiridos pelos surdos depende, para além das questões políticas, de ações didático-pedagógicas centradas em seu desenvolvimento intelectual, com vistas à superar a inadequação dos métodos utilizados em âmbito educacional e o desconhecimento de suas limitações que, consequentemente, tem retardado o despertar de sua autonomia na produção do conhecimento.

Em se tratando de formação linguística para o desenvolvimento da pessoa surda, a organização dos conteúdos de linguagem a serem ensinados deve ser pensada, criteriosamente, levando em conta a adaptação desses saberes em sintonia com as limitações/dificuldades e os modos de aprendizagem daquele sujeito. Nem sempre os conteúdos previstos no currículo são adequadamente ensinados pelo professor e nem mesmo aprendidos pelo aluno. Isso porque, conforme nos esclarece Chevallard (2013), há um distanciamento entre o que é planejado pela instituição e o que é efetivamente realizado nas práticas de ensino pelo professor e de aprendizagem pelo público discente. Essa assertiva se sustenta mediante

\footnotetext{
${ }^{1}$ De acordo com Magda Soares (2011, p. 96), o processo de letramento surge como "necessidade configurar e nomear comportamentos e práticas sociais na área da leitura e da escrita que ultrapassem o domínio do sistema alfabético e ortográfico, nível de aprendizagem da língua escrita perseguido, tradicionalmente, pelo processo de alfabetização". Neste sentido, entende-se que a língua de sinais, que está intrinsecamente inserida no contexto histórico-social do surdo, precisa ocupar o papel de protagonista neste processo.
} 


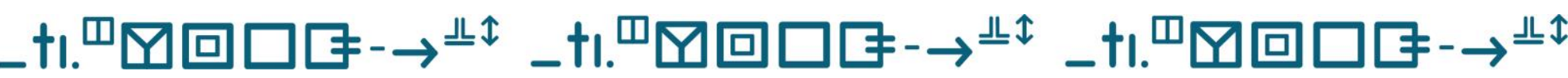

Métodos de ensino e avaliação da aprendizagem de surdos no Ensino Médio: o que dizem os profissionais de Libras-Português?

Edivaldo dos Santos Júnior • Rivadavia Porto Cavalcante et al.

procedimentos didático-pedagógicos de acordo com suas reais necessidades (FREIRE， 1996; SILVA，2005; QUADROS，2005; SILVA，2018; SANTOS e MENEZES, 2019).

Tal política de inclusão em uma sala de aula regular suscita novas competências perante as limitações, possibilidades e consequências, quando se pensa numa escola que atenda às especificidades do aluno surdo. Segundo Sally Power (2011), os problemas de implementação de uma política educacional devem ser pesquisados considerando os fatos sociais que os geram, a complexidade da realidade dos contextos locais e as vozes dos profissionais neles atuantes. Não se pode perder de vistas o "poder" desses agentes na condução dos processos de "mediação" e "ressignificação" da política nas ações educacionais (POWER, 2011, p. 59, grifos dos autores).

Partindo destes pressupostos e do quadro social complexo em que se insere professor, aluno surdo, saber de linguagem e o intérprete de LibrasPortuguês, já apresentados, para os fins deste estudo, a seguinte pergunta de pesquisa norteia seu desenvolvimento: o que revelam profissionais de Libras-Português sobre a adequação didática para o ensino dos saberes de linguagem em aulas regulares com a participação de alunos surdos em três instituições públicas de Ensino Médio do Tocantins? Para responder a este questionamento, assumimos como objetivo investigar e discutir, mediante análise dos relatos de experiência vivenciada por três profissionais de LibrasPortuguês, os métodos de ensino e de avaliação da aprendizagem utilizados em seus respectivos contextos de educação para surdos.

Justifica-se a realização deste estudo por se tratar de uma pesquisa voltada para a compreensão de problemas que afetam o desenvolvimento linguístico-cultural de pessoas surdas em contextos regulares do Ensino Médio público. Tal grupo social já tem seus direitos educacionais 


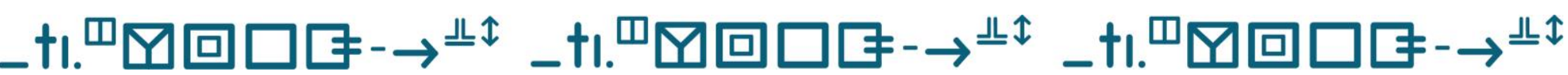

Métodos de ensino e avaliação da aprendizagem de surdos no Ensino Médio: o que dizem os profissionais de Libras-Português?

Edivaldo dos Santos Júnior • Rivadavia Porto Cavalcante et al.

consagrados na Carta Magna brasileira, que os garante uma formação para o seu "pleno desenvolvimento" e "preparo para o exercício da cidadania" (BRASIL, 1988, Art. 05).

Além disso, na atual conjuntura de pandemia imposta pela COVID-19 e do isolamento social, emerge um redimensionamento das atitudes humanas, dos modos de aprender e conceber os fatos sociais implicando a vida das populações. A compreensão deste cenário requer atualização dos saberes que, por sua vez, demandam o conhecimento das linguagens do mundo. Entretanto, não se pode ignorar o direito de os alunos surdos serem instruídos, na mesma proporção de igualdade que os ouvintes, sobre as transformações sócio-históricas em que estão inseridos. A adaptação dos saberes escolares numa perspectiva bilíngue, articulando a Língua de Sinais (LS) e a Língua Portuguesa (LP) centrados em métodos de ensino compromissados em garantir acesso aos conhecimentos necessários à participação social dos surdos é essencial para se avançar nesta direção.

Além de sua introdução, este trabalho está organizado em quatro tópicos. O primeiro discorre sobre a base teórico-conceitual do artigo, focalizando os aportes da teoria sócio-histórico-cultural de Vygotsky (1993; 1997; 2011) e de Chevallard (2000; 2013) sobre transposição didática. Estabelecemos diálogos destas teorizações com os contributos de Freire (1987; 1996), bem como de estudiosos de Libras para a educação inclusiva da pessoa surda. O segundo tópico apresenta brevemente políticas públicas inclusivas, buscando subsídios para a compreensão dos direitos educacionais de surdos previstos nos documentos oficiais do Estado. $O$ terceiro tópico aborda a caracterização metodológica do trabalho, os procedimentos de geração e análise dos dados, e o perfil dos participantes. 


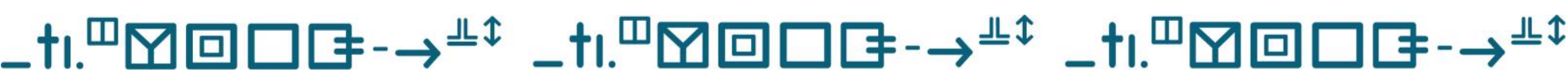

Métodos de ensino e avaliação da aprendizagem de surdos no Ensino Médio: o que dizem os profissionais de Libras-Português?

Edivaldo dos Santos Júnior • Rivadavia Porto Cavalcante et al.

Por último, discute-se o resultado das análises seguidas das conclusões do estudo.

\section{Linguagem e desenvolvimento humano: os saberes escolares}

O arcabouço teórico-conceitual deste trabalho está fundamentado, $a$ priori, na Teoria sociocultural do desenvolvimento cognitivo de Vygotsky (1993; 1997; 2011), três obras que subsidiam a construção da base de nossas próprias teorizações, posicionamentos e discussões em termos metodológicos e analíticos do objeto aqui sob estudo. Em Pensamento $e$ linguagem (1993), elaboramos a compreensão de que o mundo é feito de linguagens, as quais são entidades de significação que possibilitam as interações humanas e que, por meio destas, são gerados os sentidos dos atos comunicativos e das produções materiais e semióticas. Em Obras Escogidas, volume V, que trata sobre os fundamentos de defectología (1997), e no artigo baseado nesta última, intitulado: $A$ defectologia e o estudo do desenvolvimento e da educação da criança anormal (2011), formulamos a base conceitual de que o aluno surdo não é deficiente e nem mesmo sofredor de patologias por não ouvir o que se passa ao seu redor, mas que se trata de um sujeito que tem sua própria história e cultura de ver e compreender o mundo diferentemente dos ouvintes. Embora nem todos nós sejamos iguais em termos de capacidades, sentimentos, necessidades, entre outras dimensões humanas, valemo-nos de diferentes linguagens e leituras do mundo (FREIRE, 1996) para interagir socialmente mediante diferentes signos, tais como os símbolos, gestos, imagens, cores, textos, movimentos, ritmo, tato, odor, sons, entre outras formas de expressão. 


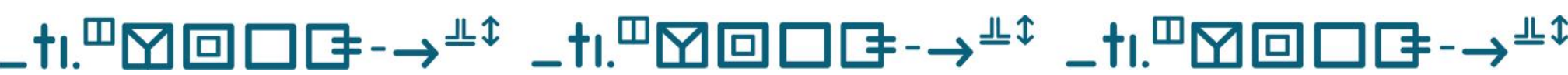

Métodos de ensino e avaliação da aprendizagem de surdos no Ensino Médio: o que dizem os profissionais de Libras-Português?

Edivaldo dos Santos Júnior • Rivadavia Porto Cavalcante et al.

Vygotsky (1993) desenvolveu suas pesquisas, levando em conta os aspectos históricos-sociais, seguindo suas origens marxistas do materialismo histórico-dialético. A interação social, para este autor, tem total relevância e influência na formação do pensamento e da linguagem, mostrando que:

Desde que, admitamos o caráter histórico do pensamento verbal, teremos que o considerar sujeito a todas as premissas do materialismo histórico, que são válidas para qualquer fenômeno histórico na sociedade humana. Só pode concluirse que a este nível o desenvolvimento do comportamento será essencialmente governado pelas leis gerais do desenvolvimento histórico da sociedade humana (VYGOTSKY, 1993, p. 55).

Estas premissas do materialismo histórico citado por Vygotsky (1993) fomentam as bases do conceito de educação humana numa perspectiva de formação omnilateral. O termo omnilateral é utilizado nesta pesquisa, de acordo com Manacorda (2007), se propondo a uma formação ampla e integral, para além da dicotomia entre trabalho intelectual e trabalho manual, considerando o trabalho como dimensão ontológica do ser humano e como princípio educativo. Esses construtos possibilitam refletir e analisar os processos de escolarização e as práticas de ensino e aprendizagem nas salas de aula como espaços de interação social e zona de desenvolvimento humano, já que a escola é um lugar de socialização de pessoas e de conhecimentos. Esta visão teórica subverte o modelo de educação conteudista voltado para a implementação de normas dos interesses capitalistas do Estado, deixando de lado o desenvolvimento pleno da população estudantil.

No que se refere à educação do aluno surdo, os estudos vygotskyanos trazem contribuições bastante pertinentes que auxiliam a desmistificar representações negativas construídas ao longo da história das sociedades 


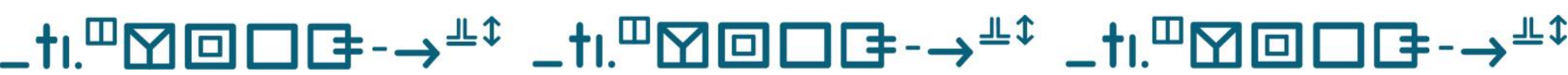

Métodos de ensino e avaliação da aprendizagem de surdos no Ensino Médio: o que dizem os profissionais de Libras-Português?

Edivaldo dos Santos Júnior • Rivadavia Porto Cavalcante et al.

sobre o sujeito, dentre essas, a patologização de sua condição e de suas necessidades especiais, isto é, como uma pessoa deficiente e não como um ser constituído de forma histórica e cultural. Conforme elucida o estudioso russo, "atualmente, a questão consiste em romper o aprisionamento biológico da psicologia e passar para o campo da psicologia histórica, humana". (VYGOTSKY, 2011. p. 864). Tal assertiva leva ao entendimento de que, em nosso tempo, ainda persiste a concepção dos sujeitos surdos como se não fossem seres humanos e sociais, porém ainda percebidos sob a ótica biologizante do ser.

No que tange ao surdo, sua educação no decorrer da história tem sido marcada pela tentativa de transformá-lo em um surdo oralizado de modo arbitrário. Isso porque a plataforma patológica que concebe este sujeito como tal o coloca na condição de "ouvinte deficiente". Nesta concepção clínico-terapêutica da surdez, pressupõe - se que o surdo sofre uma patologia, necessitando, portanto, de tratamento mediante método de oralização, sem levar em consideração a especificidade identitária e cultural da comunidade surda.

De modo consequente, esse modelo metodológico tem exercido forte influência sobre a educação de surdos, implantando perspectiva de anormalidade e de incapacidade do desenvolvimento social e intelectual desses sujeitos, bem como impedindo a possibilidade de se tornarem cada vez mais comunicativos (GESSER, 2008).

A respeito dessas asserções, Vygotsky nos apresenta um modelo conceitual que supera o método de oralização com foco nos diferentes modos de comunicação humana fomentados nas e pelas distintas práticas de linguagens do ambiente social. Segundo o autor, a fala não está obrigatoriamente ligada ao aparelho fonador; mas pode ser realizada em 


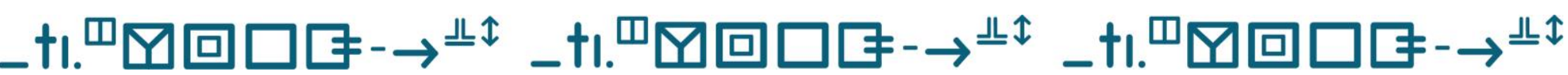

Métodos de ensino e avaliação da aprendizagem de surdos no Ensino Médio: o que dizem os profissionais de Libras-Português?

Edivaldo dos Santos Júnior • Rivadavia Porto Cavalcante et al.

outro sistema de signos, assim como a escrita pode ser transferida do caminho visual para o tátil (VYGOTSKY, 2011).

Conforme revelado no excerto em tela, o modelo vygotskyano amplia o ato de falar para além da dimensão biológica do humano, o aparelho fonador, demonstrando que o ato comunicativo emerge e se desenvolve mediante outros signos, além do puramente oral-auditivo. A exemplo da Libras, de natureza visuo-espacial. O modelo que se trata por ora revela uma perspectiva centrada na diversidade da linguagem e não da deficiência, isto é, na ausência de audição e do aparelho fonador como única forma de comunicação.

Assim posto, adotamos o termo diferença ao invés de deficiência para nos referir à pessoa surda. O primeiro pressupõe uma plataforma de respeito, quanto ao segundo, está carregado de preconceitos patológicos, enxergando a pessoa pelo que Ihe falta, no caso do surdo, a audição. Segundo Felipe (2006),

Ser surdo é saber que pode falar com as mãos e aprender uma língua oral-auditiva através dessa, é conviver com pessoas que, em um universo de barulhos, deparam-se com pessoas que estão percebendo o mundo, principalmente, pela visão, e isso faz com que eles sejam diferentes e não necessariamente deficientes (FELIPE, 2006, p. 43).

O aporte de Felipe converge com os pressupostos vygotskyanos e coaduna com os princípios adotados neste trabalho de que, além de respeitar as diferenças, as condições e as limitações humanas, é preciso igualmente aceitar a diversidade e a pluralidade cultural do contexto social em que estão inseridos. Por essa razão, argumentamos a favor de uma educação integradora para a formação humana, priorizando na construção 


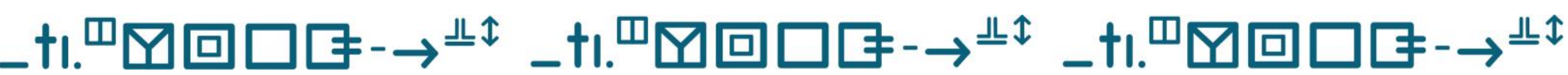

Métodos de ensino e avaliação da aprendizagem de surdos no Ensino Médio: o que dizem os profissionais de Libras-Português?

Edivaldo dos Santos Júnior • Rivadavia Porto Cavalcante et al.

de seus métodos de ensino e aprendizagem os valores sócio-históricos e culturais da população surda.

Além de proposições para a superação da psicologia biologizante, a abordagem interacionista e histórico-social de Vygotsky (1997) traz contribuições pertinentes para a compreensão dos entraves que regem a funcionalidade dos métodos de ensino e aprendizagem voltados para o surdo. Em suas palavras, “o problema da linguagem $\operatorname{dos}_{\text {surdos }}^{2}[$ [...] não será resolvido por um método especial, mas pela reestruturação geral da escola com base nos princípios da educação social"33 (VYGOTSKY, 1997, p. 34, grifo e tradução dos autores). Este postulado orienta nossa pressuposição de que a "reestruturação" da escola para os surdos depende da adequação de seus métodos de ensino e avaliação da aprendizagem dos saberes a ensinar e ser aprendido por aqueles educandos, posto que são sujeitos sociais. Para tanto, os aportes teórico-metodológicos de Chevallard (2013) sobre transposição didática interna, que discutiremos no próximo tópico, subsidiam de forma bastante coerente a compreensão da adequação dos métodos e avaliação dos saberes escolares a serem ensinados e aprendidos em contextos escolares.

\subsection{Transposição didática: uma compreensão da adequação dos saberes escolares}

\footnotetext{
2 O termo "surdo e mudo" utilizado por Vygotsky, se tornou obsoleto, conforme Gesser (2008), pois sabe-se que a maioria das pessoas com surdez não apresenta problemas nas pregas vocais. Por isso, não são surdos-mudos, e sim Surdos, podendo este optarem em falar por meio de uma língua oral ou não.

3 Tradução nossa de: El problema del lenguaje en los sordomudos no será solucionado por un método especial, sino por la reestructuración general de la escuela basada en los principios de la educación social.
} 


\section{_t..}

Métodos de ensino e avaliação da aprendizagem de surdos no Ensino Médio: o que dizem os profissionais de Libras-Português?

Edivaldo dos Santos Júnior • Rivadavia Porto Cavalcante et al.

Conforme já antecipado no tópico anterior, a escola e a sala de aula são espaços sociais de produção de conhecimentos e de desenvolvimento humano. Porém, esta asserção merece uma reflexão aprofundada sobre o processo de escolarização.

As teorizações de Chevallard (2013) apontam que educadores precisam compreender criticamente o processo de transformação e ressignificação que o conhecimento formulado nas academias científicas sofre ao se tornar conhecimento escolar. Dito em outros termos, convertido em objeto de ensino e de aprendizagem nas salas de aula. Em virtude disso, muitas vezes o ensino dos saberes escolares tende a ser percebido como "uma tarefa altamente artificial". Por conseguinte, são as transformações adaptativas feitas para que se tornem adequados e assimiláveis às reais condições do aluno - ensinados e aprendidos - "que eu tenho chamado de transposição didática do conhecimento" (CHEVALLARD, 2013, p. 9).

O termo "transposição didática" é oriundo da obra do sociólogo francês Michel Verret, voltada para a didática do ensino de matemática, e retomado por Yves Chevallard, em 1985, no seu livro La transposition didactique: du savoir savant au savoir enseigné". (ROSA; LOCATELLI, 2018, p. 28). Essa base teórica possibilita refletir que a concretização de uma política educacional voltada para a formação humana geral requer levar em conta não apenas orientação de teorias científicas e acadêmicas, de documentos oficiais do Estado ou mesmo do currículo institucional. Isto porque transformações adaptativas do teor das referidas orientações devem ser feitas em sintonia com a especificidade e necessidade do público estudantil, limitações dos educadores e dos contextos escolares.

Chevallard $(2000,2013)$ desenvolve um modelo de compreensão das transformações adaptativas que os saberes escolares (conteúdos 


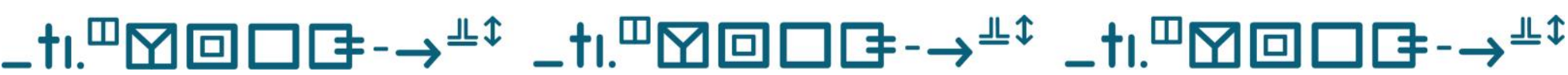

Métodos de ensino e avaliação da aprendizagem de surdos no Ensino Médio: o que dizem os profissionais de Libras-Português?

Edivaldo dos Santos Júnior • Rivadavia Porto Cavalcante et al.

disciplinares) sofrem desde suas origens em um dado campo científico até chegar à sala de aula (campo de negociação entre professor e aluno na construção do conhecimento) nos eventos de ensino-aprendizagem. Segundo o autor, o saber científico é aquele concebido na academia, nas universidades. Para que esse saber chegue ao aluno do Ensino Médio, por exemplo, precisa ser transposto e/ou adaptado de forma que se torne compreensível, ensinável e efetivamente aprendido pelos alunos (CHEVALLARD, 2000).

A Figura 1 coloca em destaque os dois processos de adaptação que constituem os saberes escolares: a transposição externa, denominada stricto sensu, e a transposição interna, denominada lato sensu (CHEVALLARD, 2000, 2013). O primeiro concerne a transformação do saber científico em saber escolar. De ordem do contexto externo à instituição educacional suas adaptações ocorrem no momento da "seleção dos conteúdos de saber a ensinar até a chegada na escola" (ROSA e LOCATELLI, 2018, p. 28). O segundo se dá no contexto interno dessa organização social, em que as orientações do processo anterior são transformadas e adaptadas mediante o trabalho didático-pedagógico do professor em objeto (conteúdos) de ensino e de aprendizagem na sala de aula com os alunos, bem como em procedimentos avaliativos. 


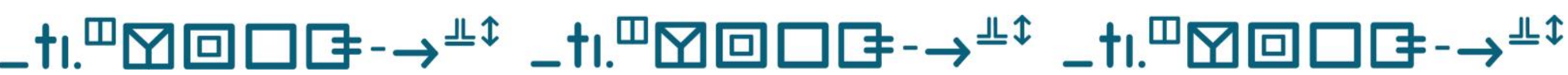

Métodos de ensino e avaliação da aprendizagem de surdos no Ensino Médio: o que dizem os profissionais de Libras-Português?

Edivaldo dos Santos Júnior • Rivadavia Porto Cavalcante et al.

Figura 1. Transposição Didática dos Saberes

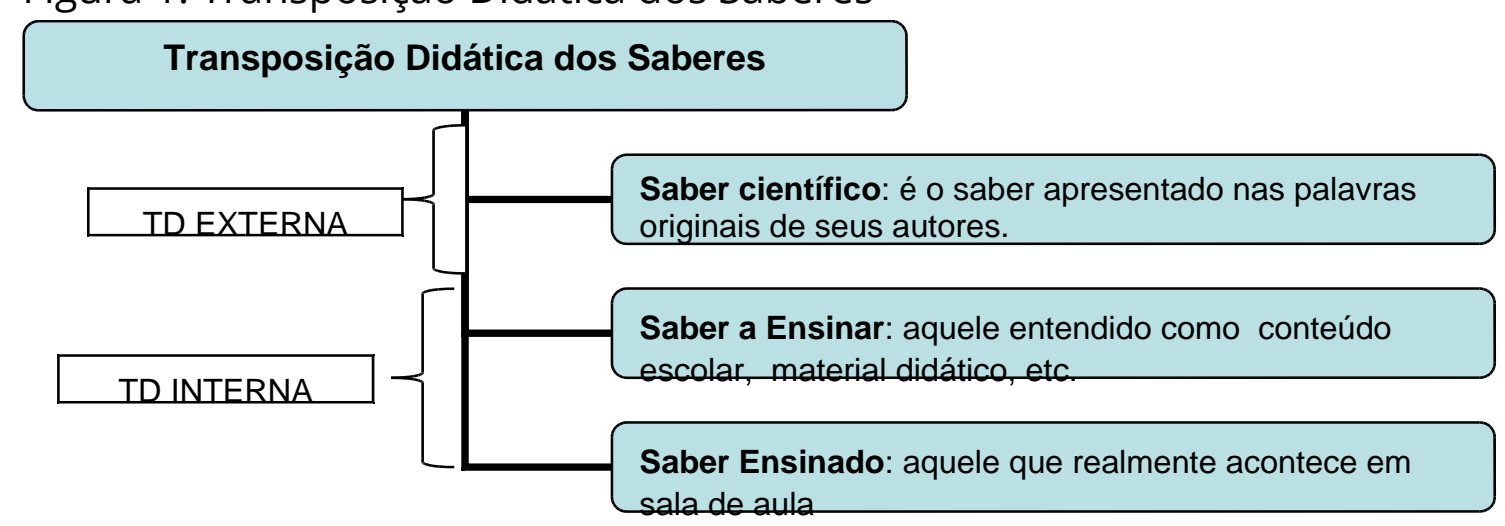

Fonte: Elaborado pelos autores com base em Chevallard (2000; 2013).

Descrição da imagem: Figura intitulada "Transposição Didática dos Saberes". A Figura é composta por um organograma contendo a Transposição didática dos Saberes de Yves Chevallard (2000; 2013), apresentando a Transposição Didática Externa e a Transposição Didática Interna e suas ramificações.

Neste trabalho, optamos pela investigação do processo de transposição didática interna com vistas a compreender como ocorre a adaptação dos métodos de ensino e avaliação da aprendizagem de surdos em contexto escolar interno. Assim sendo, detemo-nos brevemente sobre algumas considerações teóricas a respeito da relevância de compreender tal processo.

A esse respeito, Chevallard (2013) salienta que o ambiente da classe em lócus de interação se dá por meio da relação didática constituída por uma tríade, implicando o professor, o aluno e o saber escolar. Esse último, por sua vez, se refere às transformações adaptativas que o docente deve trabalhar de acordo com sua competência teórica-metodológica, empreendendo o ajuste de seu método às condições e necessidades específicas de seus alunos. Dito em outros termos, tais adaptações dependem de sua base de conhecimento em transformar e adequar os conteúdos curriculares e/ou disciplinares, instrumentos materiais e semióticos em saberes ensináveis. 


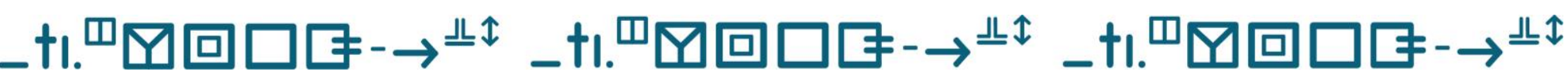

Métodos de ensino e avaliação da aprendizagem de surdos no Ensino Médio: o que dizem os profissionais de Libras-Português?

Edivaldo dos Santos Júnior • Rivadavia Porto Cavalcante et al.

Todavia, tal processamento de adequação dos métodos de ensino não se trata de uma mera simplificação dos conhecimentos que se pretende trabalhar, mas da relevância destes para o desenvolvimento da formação escolarizada do discente, denominada pelo autor de vigilância epistemológica (CHEVALLARD, 2000). Este termo se refere ao fato de que a prática de ensino e aprendizagem é também uma prática de adaptações dos conhecimentos para que se possa alcançar os propósitos da educação e da formação humana, já que tais contextos e a aprendizagem dos sujeitos são caracterizados pela heterogeneidade.

Em uma visão crítica do caráter utilitário e didático do conhecimento, o autor chama atenção para o fato de que, na maioria das sociedades, os conhecimentos são produzidos para serem mais usados do que realmente ensinados. Logo, neste ponto de vista, para que a prática de ensino não incorra em uma ação artificial é preciso que os educadores compreendam a complexidade em que reside a sua implementação, posto que, historicamente, "o ensino nunca foi uma atividade fácil e natural" (CHEVALLARD, 2013, p. 9). Sendo, portanto, uma atividade que requer conhecimentos diversos, o autor representa em sua obra a atividade de ensinar como uma grande aventura, principalmente no que se refere ao desafio de articular ensino e cultura numa perspectiva de interação e de prática social.

Nessa direção, os aportes de Chevallard (2013, p. 9) nos instruem que não se pode anular a cultura nos processos de ensino, devendo, pois, levar em conta "conceitos culturalmente aceitos". O grande problema que se apresenta na prática social é o viés binário que se tem da realidade, isto é, uns sabem e outros não sabem, sempre numa perspectiva dicotômica. 


\section{_t..}

Métodos de ensino e avaliação da aprendizagem de surdos no Ensino Médio: o que dizem os profissionais de Libras-Português?

Edivaldo dos Santos Júnior • Rivadavia Porto Cavalcante et al.

\subsection{Questões de organização e adequação dos saberes na educação de surdos}

Além das contribuições de Yves Chevallard, os saberes escolares e suas adaptações no processo ensino e aprendizagem são objeto de discussão na obra de Paulo Freire. Os pressupostos deste pensador da Pedagogia da Autonomia (1996) nos auxiliam a compreender os saberes fundamentais que o professor precisa se apropriar para a realização de seu trabalho no campo da prática educativa de surdos.

A perspectiva educativo-progressista de Freire (1996) nos mostra que ensinar e aprender são ações conjuntas que devem priorizar em torno dos saberes do mundo e dos saberes escolares o desenvolvimento da autonomia do aluno na produção dos conhecimentos necessários à sua vida. Em suas reflexões, o autor chama atenção para o fato de que ensinar requer do educador compreender as diferenças sociais, contextos e as condições de vida de seu público discente. Precisa estar ciente de que sua atuação na prática educativa tem compromissos com a atualização contínua de sua base de conhecimento teórico e geral.

Freire enfatiza que "saber ensinar não é transferir conhecimento, mas criar as possibilidades para a sua própria produção ou a sua construção" (FREIRE, 1996, p. 5). No caso do educador de surdos, esta assertiva subsidia o entendimento de que não se aplica dotar o aluno apenas com os conteúdos disciplinares da escola regular, mas que tais conteúdos sejam o ponto de partida para que professor e aluno avancem na cultura de produção de conhecimentos que fomentem outros, possibilitando assim, o desenvolvimento da consciência crítica e a autonomia do aluno.

Esta reflexão crítica sobre o fazer didático-pedagógico do educador nos leva à compreensão de que, na relação teórico-prática do processo de 


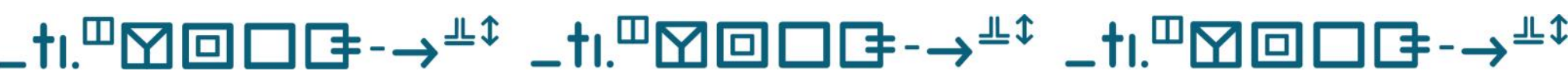

Métodos de ensino e avaliação da aprendizagem de surdos no Ensino Médio: o que dizem os profissionais de Libras-Português?

Edivaldo dos Santos Júnior • Rivadavia Porto Cavalcante et al.

ensino-aprendizagem para surdos, é preciso criar possibilidades para que o educando reconheça seu direito e seu papel social na produção do saber. Para Freire (1996, p. 48), não bastam as afirmações teóricas, pois estas só ganham sentidos quando há um "exemplo concreto, prático, da teoria. Sua encarnação", ou seja, quando vivenciadas em situações reais e significativas para o aluno.

No caso do aluno surdo, os argumentos freireanos servem de caminho para que o educador empreenda a criação de ambientes favoráveis de aprendizagem, propiciando-Ihe vivenciar práticas efetivas de construção e a reconstrução do conhecimento. Inseri-lo em práticas interativas, a partir dos saberes prévios de sua cultura surda com a cultura dos ouvintes. Valorizar as linguagens que delas emergem (os signos, escritos, imagéticos, entre outros ao modo vygotsykyano), o que pressupõe a aceitação e o respeito das diferenças humanas. Numa demonstração de que o surdo tem o direito de perceber que o mundo em que está inserido é plural.

Nesta perspectiva, os aportes de Quadros (2005) chamam atenção para a função importante das práticas bilíngues e do biculturalismo para o desenvolvimento omnilateral do aluno surdo, isto é, a comunicação mediada por línguas distintas em diferentes esferas sociais, o que pressupõe uma educação bilíngue por meio da L1 (primeira língua) e da L2 (segunda língua), a qual ainda não ganhou relevo considerável nos contextos escolares brasileiros. Em vista disso, a autora argumenta que a Libras funciona, nesse âmbito, como "coadjuvante" enquanto o português assume "papel principal" nas instruções escolares. A sobreposição desta em detrimento daquela no processo se caracteriza "práticas de exclusão" da língua do surdo (QUADROS, 2005, p. 3). 


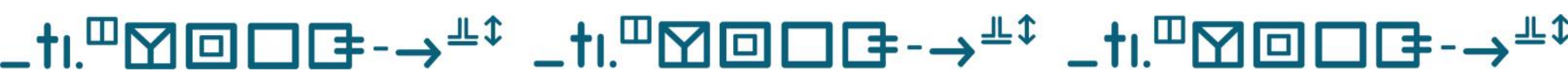

Métodos de ensino e avaliação da aprendizagem de surdos no Ensino Médio: o que dizem os profissionais de Libras-Português?

Edivaldo dos Santos Júnior • Rivadavia Porto Cavalcante et al.

Os apontamentos de Quadros (2005) suscitam reflexões de que sustentar uma hierarquia linguística nos espaços escolares é o mesmo que não reconhecer a pluralidade cultural da população estudantil. A autora adverte que, embora a L1 esteja presente nos ambientes de ensino, sua marginalização tem sido evidente. Persiste ainda a visão de que a Libras não é uma língua, de facto, entendida ainda como gestos soltos e desconexos. À guisa de exemplo, é notório no processo de avaliação da aprendizagem a valorização da L2, o português, em detrimento da L1. Sobre tal contradição, Felipe (2006, p. 07) assevera que, atualmente, seria um gesto preconceituoso e ingênuo alegar a favor da superioridade de uma língua sobre a outra, "enquanto sistema linguístico, independem dos fatores econômicos ou tecnológicos, não podendo ser classificadas em desenvolvidas, subdesenvolvidas ou, ainda, primitivas".

Os estudos de Quadros (2005) e de Felipe (2006) nos mostram um descompasso na organização dos saberes de linguagem no contexto de educação regular "dita" inclusiva. No processo de escolarização do surdo, a LS, enquanto fenômeno linguageiro, possibilita a interação e a socialização deste com aqueles ao seu redor, constituindo-se como base essencial para seu desenvolvimento pleno (VYGOTSKY, 1993, 2011). Outrossim, trata-se de um elemento cultural importante do universo da população surda, por meio do qual procede-se a produção de seus conhecimentos de mundo (FREIRE, 1996; QUADROS, 2005; SKLIAR, 2017). Portanto, tal educação não condiz com um ambiente favorável ao surdo.

Na mesma direção, Silva (2005, p. 37) chama atenção para os problemas de inadequação do ensino dos conteúdos na educação de surdos, pois "há um imenso abismo entre o mundo acadêmico e o cotidiano escolar". Sua pesquisa nos traz resultados que suscitam reflexões sobre o caráter 


\section{_t..}

Métodos de ensino e avaliação da aprendizagem de surdos no Ensino Médio: o que dizem os profissionais de Libras-Português?

Edivaldo dos Santos Júnior • Rivadavia Porto Cavalcante et al.

deficitário dessa modalidade educacional e a simplificação do currículo, desconsiderando a vigilância epistemológica (CHEVALLARD, 2013). Por causa disso, muitos surdos terminam sua escolarização básica sem o domínio dos conteúdos pertinentes a este nível e sem uma educação que os prepare para o exercício de sua cidadania, conforme prevista no Artigo 05 da Constituição Brasileira (BRASIL, 1988).

Além do exposto, a mediação dos saberes escolares em sala de aula é outro problema que carece de alternativas, notadamente na relação didática envolvendo professor, aluno surdo, saber a ensinar e o intérprete. $\mathrm{Na}$ maioria dos casos, o docente não sabe como lidar com as singularidades desse discente (QUADROS, 2005; FELIPE, 2006; SKLIAR, 2017), deixando, portanto, suas atividades a cargo do intérprete. Todavia, o Artigo $2^{\circ}$ da Lei $n^{\circ}$. 12.319 de $1^{\circ}$ de setembro de 2010 determina que o Intérprete de LibrasPortuguês deve "realizar interpretação das (duas) línguas de maneira simultânea ou consecutiva" (BRASIL, 2010), auxiliando professor e aluno no processo ensino e aprendizagem. Logo, não cabe a ele ensinar conteúdos aos surdos.

Nessa circunstância, tal problemática se alinha à escassez de ações que visem implementar, de fato, a política educacional de inclusão constante dos documentos orientadores para a formação inicial e continuada de professores, bem como de outros profissionais para atuação nesse contexto de formação humana. A interação professor-intérprete de forma cooperativa e sintonizada com a cultura bilíngue do surdo pode ser bastante profícua para o engajamento deste com os demais discentes da sala de aula regular. No próximo tópico discutimos, brevemente, alguns documentos reguladores nesta direção. 


\section{_tı.}

Métodos de ensino e avaliação da aprendizagem de surdos no Ensino Médio: o que dizem os profissionais de Libras-Português?

Edivaldo dos Santos Júnior • Rivadavia Porto Cavalcante et al.

\section{Políticas públicas para a inclusão do surdo}

No contexto escolar brasileiro, a educação de surdos só se tornou oficial após a declaração de Salamanca (UNESCO, 1994). Tal diretriz internacional é a continuidade dos movimentos da Conferência Mundial sobre Educação para Todos, em Jomtien, Tailândia, de 5 a 9 de março de 1990 (UNESCO, 1990), que priorizam a universalização do ensino regular para todos. Essas convenções internacionais influenciaram a formulação dos principais marcos legais para educação da população surda no Brasil, fomentando seus direitos, já reconhecidos, nos Artigos 05, 06 e 08 da Constituição Federal (BRASIL, 1988). Em observância à essas disposições, cumpre ao Estado garantir seus direitos de igualdade, acesso, permanência e atendimento especializado na escola. Porém, não ainda implementados em conformidade com os anseios da comunidade surda nos contextos educacionais.

Em meio à reivindicações de membros e representantes desse grupo social e das contradições das políticas públicas brasileiras, a educação voltada para esta classe ganhou relevo considerável com a Lei n. 9.394/1996, que estabelece as diretrizes e bases da educação nacional (LDB), seus princípios e finalidades ratificando o disposto no texto constitucional. Esta política reitera os ideais dos movimentos internacionais de educação igualitária para todos. Por isso, determina que educação e atendimento para o aluno com necessidade educativa especial se realizem "em todos os níveis, etapas e modalidades, preferencialmente na rede regular de ensino" (BRASIL, 1996, Artigo 4 , parágrafo III). Quadros (2003) aponta contradições no modo como esta política de inclusão vem sendo desenvolvida, já que o texto de lei em questão, ao adotar os princípios de educação para todos, homogeneíza 


\section{_t..}

Métodos de ensino e avaliação da aprendizagem de surdos no Ensino Médio: o que dizem os profissionais de Libras-Português?

Edivaldo dos Santos Júnior • Rivadavia Porto Cavalcante et al.

os grupos sociais como se todos fossem iguais. Como se tal política de inclusão pudesse beneficiar "cegos, surdos, entre outros" sem considerar suas especificidades, singularidades comunicativas e necessidades educativas (SANTOS; BORDAS, 2009, p. 63).

Outros dispositivos legais se despontaram, a partir das disposições da LDB. Dentre estes, destaca-se a Lei Federal n. 10.436/02, de 24 de abril de 2002, que se configura como um dos principais marcos da conquista da comunidade surda. Reconhece e regulamenta a Libras, a qual deve ser a L1 dessa classe social, como "um sistema linguístico de transmissão de ideias e fatos, oriundos de comunidades de pessoas surdas do Brasil", possibilitando comunicação e expressão em suas interações sociais (BRASIL, 2002, Art 1%).

O Decreto Federal n. 5.626/05, de 22 de dezembro de 2005, é outro documento importante das lutas da comunidade surda e que regulamenta a lei citada e determina a compulsoriedade da Libras em cursos de formação do profissional docente, tradutor e intérprete, entre outras modalidades, além do reconhecimento de proficiência mediante certificação em exame nacional. O Quadro 1 explicita uma visão de conjunto dos documentos (internacionais e nacionais) que amparam e subsidiam a inclusão dos alunos surdos.

Quadro 1 - Documentos oficiais para a educação inclusiva de surdos.

Declaração Universal dos Direitos Humanos (DUDH) de 1948 "Todo ser humano tem direito à instrução" (ONU, 1948, Artigo 26)

Constituição da república federativa do Brasil de 1988: "A educação, direito de todos e dever do Estado e da família, será promovida e incentivada com a colaboração da sociedade, visando ao pleno desenvolvimento da pessoa, seu preparo para o exercício da cidadania e sua qualificação para o trabalho". (BRASIL, 1988, Artigo 205). 


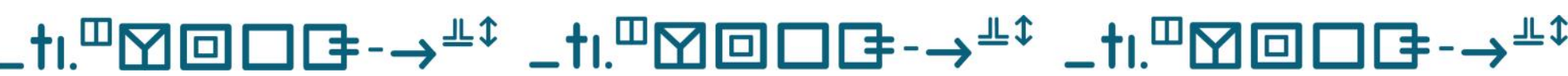

Métodos de ensino e avaliação da aprendizagem de surdos no Ensino Médio: o que dizem os profissionais de Libras-Português?

Edivaldo dos Santos Júnior • Rivadavia Porto Cavalcante et al.

Declaração Mundial sobre Educação para Todos (Conferência de Jomtiem -1990): “As necessidades básicas de aprendizagem das pessoas portadoras de deficiências requerem atenção especial. É preciso tomar medidas que garantam a igualdade de acesso à educação aos portadores de todo e qualquer tipo de deficiência, como parte integrante do sistema educativo" (UNESCO, 1990, p. 4).

Declaração de Salamanca: "A importância da linguagem de signos como meio de comunicação entre os surdos, por exemplo, deveria ser reconhecida e provisão deveria ser feita no sentido de garantir que todas as pessoas surdas tenham acesso a educação em sua língua nacional de signos" (UNESCO, 1994).

Lei 9.394/96 - Lei de Diretrizes e Bases - LDB: “Entende-se por educação especial, para os efeitos desta Lei, a modalidade de educação escolar oferecida preferencialmente na rede regular de ensino, para educandos com deficiência, transtornos globais do desenvolvimento e altas habilidades ou superdotação" (BRASIL, 1996, Artigo 58).

Diretrizes da Educação Especial na Educação Básica - Resolução CNE/CEB no. 02/2001: “Os Sistemas de Ensino devem matricular todos os alunos, cabendo às escolas organizarem-se para o atendimento aos educandos com necessidades educacionais especiais, assegurando as condições necessárias para uma educação de qualidade para todos" (BRASIL, 2001, Artigo 2º).

Lei $n^{\circ} .10 .436$ de 24 de abril de 2002. Dispõe sobre a Língua Brasileira de Sinais - Libras e dá outras providências (BRASIL, 2002).

Decreto 5.626 de 22 de dezembro de 2005: Regulamenta a Lei $n^{0} 10.436$, de 24 de abril de 2002, que dispõe sobre a Língua Brasileira de Sinais - Libras, e o art. 18 da Lei n 10.098, de 19 de dezembro de 2000 (BRASIL, 2005).

Política Nacional de Educação Especial na Perspectiva da Educação Inclusiva - 2008: "Para o ingresso dos estudantes surdos nas escolas comuns, a educação bilíngüe - Língua Portuguesa/Libras desenvolve o ensino escolar na Língua Portuguesa e na língua de sinais, o ensino da Língua Portuguesa como segunda língua na modalidade escrita para estudantes surdos, os serviços de tradutor/intérprete de Libras e Língua Portuguesa e o ensino da Libras para os demais estudantes da escola" (BRASIL, 2008, Cap. VI ).

Lei 12.319 de $1^{\circ}$ de setembro de 2010. Regulamenta a profissão de Tradutor e Intérprete da Língua Brasileira de Sinais - Libras (BRASIL, 2010).

Lei 13.146/15 - Lei Brasileira de Inclusão - LBI. Regulamenta a profissão de Tradutor e Intérprete da Língua Brasileira de Sinais - Libras: "oferta de educação bilíngue, em Libras como primeira 


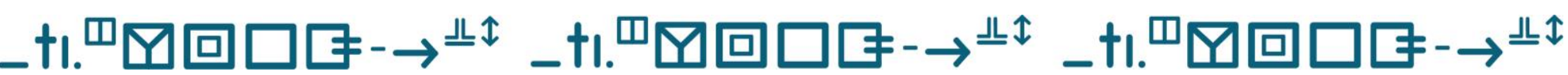

Métodos de ensino e avaliação da aprendizagem de surdos no Ensino Médio: o que dizem os profissionais de Libras-Português?

Edivaldo dos Santos Júnior • Rivadavia Porto Cavalcante et al.

língua e na modalidade escrita da língua portuguesa como segunda língua, em escolas e classes bilíngues e em escolas inclusivas" (BRASIL, 2015, Artigo 28).

Fonte: Elaborado pelos autores (2021).

Descrição da imagem: Quadro intitulado “Documentos oficiais para a educação inclusiva de surdos". Trata-se de um quadro que expõe documentos internacionais e nacionais que versam sobre a inclusão de surdos.

Considerando o repertório de documentos oficiais norteadores da educação e inserção do aluno surdo na escola, revisados neste tópico, observa-se que este público estudantil tem seus direitos educacionais garantidos. Apesar disso, percebe-se que o problema que se abate sobre o desenvolvimento intelectual do aluno surdo para sua inclusão social não está relacionado apenas às questões de ordem política, conforme os direitos conquistados até o momento por este público estudantil nos textos oficiais do Quadro 1. O cerne dos entraves neste âmbito é também de ordem didático-pedagógica e metodológica do ensino e aprendizagem.

\section{Percurso metodológico do estudo}

No desenvolvimento deste trabalho, mobilizamos o modelo de pesquisa qualitativa, que, do ponto de vista de seus objetivos, se enquadra como estudo exploratório. Segundo Gil (2008), tal modo de encarar a pesquisa, em contexto educacional, possibilita uma compreensão mais holística dos fenômenos envolvendo situações que carecem de investigação para se obter maior familiaridade com a problemática. Além disso, essa forma de abordagem do objeto sob estudo permite formular interpretações sobre percepções e sentidos atribuídos pelos humanos a respeito dos fenômenos do universo social em que estão inseridos (FLICK, 2009). 


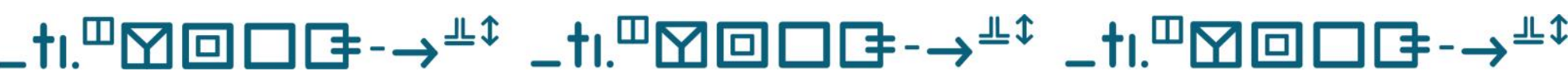

Métodos de ensino e avaliação da aprendizagem de surdos no Ensino Médio: o que dizem os profissionais de Libras-Português?

Edivaldo dos Santos Júnior • Rivadavia Porto Cavalcante et al.

Em termos de seus procedimentos técnicos, este trabalho partiu, primeiramente, da pesquisa bibliográfica com revisão de materiais já publicados (KAUARK; MANHÃES; MEDEIROS, 2010), isto é, obras de autores as quais constam do referencial teórico do artigo, servindo de subsídios para as análises. Empreenderam-se diálogos entre a base teórica vygotskyana e da transposição didática com a perspectiva educativa freireana e de estudiosos das políticas públicas educacionais para surdos. Além disso, o trabalho contou com pesquisa documental de textos oficiais reguladores da educação inclusiva da pessoa surda e estudo de caso. Tais procedimentos nos permitiram investigar e entender fenômenos individuais (GIL, 2008; YIN, 2010). Serviram-nos de estratégia para explorar e compreender, com mais profundidade, os fenômenos que regem os respectivos contextos de atuação dos participantes do estudo e as percepções destes sobre suas experiências na sala de aula regular do Ensino Médio público, onde ocorrem as interações entre professor, aluno surdo, saber de linguagem e profissional de LibrasPortuguês.

Para a geração dos dados, realizamos entrevistas semiestruturadas com vistas a relatar algumas experiências de profissionais da educação que têm atuado no ensino de surdos em escolas inclusivas, perguntando-lhes a respeito de métodos de ensino e avaliação que têm sido realizados com os discentes surdos nos seus respectivos contextos educacionais. As entrevistas foram realizadas via dispositivos digitais (WhatsApp e Google-Meet), com participação de três Profissionais de Libras-Português (denominados respectivamente P1, P2 e P3), atuantes no Ensino Médio público no estado do Tocantins, no mês de junho de 2020. Segundo Flick (2009) e Yin (2010), essa técnica auxilia na geração de dados autênticos, possibilitando ao entrevistado expor seus relatos acerca de sua vivência e de seu ponto de 


\section{_tı.}

Métodos de ensino e avaliação da aprendizagem de surdos no Ensino Médio: o que dizem os profissionais de Libras-Português?

Edivaldo dos Santos Júnior • Rivadavia Porto Cavalcante et al.

vista de forma natural. Nesse trabalho, tais relatos são discursos reveladores de ocorrência das práticas educacionais, no terreno da política de ensino (POWER, 2009), dos respectivos contextos de atuação dos participantes do trabalho. Seus enunciados explicitam a disparidade entre o que está determinado pela legislação e o que se tem em termos de resultado da implementação do ensino de linguagem para surdos até o momento de nossa interlocução com aqueles educadores.

As experiências vivenciadas por esses atores sociais, no Ensino Médio público com alunos surdos, motivaram nossos interesses e opções em buscá-los como colaboradores desta pesquisa. O Quadro 2 esboça tanto o perfil profissional quanto o papel social por eles assumidos nesse campo de formação humana. Por uma questão de ética em pesquisa e respeito aos colaboradores, seus nomes e a razão social das instituições onde atuam foram omitidos.

Quadro 2 - Perfil profissional e papel social dos participantes da pesquisa

\begin{tabular}{|c|c|c|c|c|}
\hline \multicolumn{2}{|c|}{ Formação profissional } & Atuação & Experiência & Local de atuação \\
\hline P1 & $\begin{array}{c}\text { Bacharelado+Licenciatura } \\
\text { Português-Libras }\end{array}$ & $\begin{array}{c}\text { Professor/Intérprete } \\
\text { Ensino Médio }\end{array}$ & 15 anos & $\begin{array}{c}\text { Escola pública } \\
\text { estadual/municipal }\end{array}$ \\
\hline P2 & $\begin{array}{c}\text { Licenciatura+Especialização } \\
\text { Português-Libras }\end{array}$ & $\begin{array}{c}\text { Professor/Intérprete } \\
\text { Ensino Médio }\end{array}$ & 4 anos & $\begin{array}{c}\text { Escola pública } \\
\text { federal }\end{array}$ \\
\hline P3 & $\begin{array}{c}\text { Licenciatura+Especialização } \\
\text { Português-Libras }\end{array}$ & $\begin{array}{c}\text { Professor/Intérprete } \\
\text { Ensino Médio }\end{array}$ & 15 anos & $\begin{array}{c}\text { Escola pública } \\
\text { federal }\end{array}$ \\
\hline
\end{tabular}

Fonte: Elaborado pelos autores (2021).

Descrição da imagem: Quadro 2 intitulado "Perfil profissional e papel social dos participantes da pesquisa". O Quadro 2, disposto em uma tabela de 5 colunas e 4 linhas, apresenta o perfil dos profissionais participantes da pesquisa.

Quanto aos procedimentos analíticos das entrevistas, recorremos à técnica de análise de conteúdo de material comunicativo proposta por Bardin (2011). Para tanto, procedemos primeiramente à leitura e transcrição dos relatos das entrevistas. Em seguida, apresentamos a organização dos 


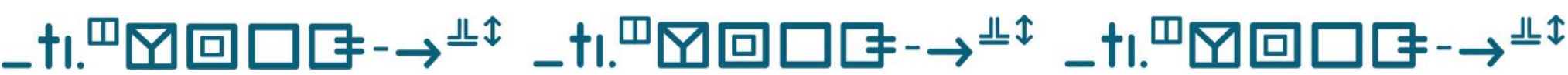

Métodos de ensino e avaliação da aprendizagem de surdos no Ensino Médio: o que dizem os profissionais de Libras-Português?

Edivaldo dos Santos Júnior • Rivadavia Porto Cavalcante et al.

relatos em duas categorias de análises, quais sejam: método concernente às adaptações do ensino de linguagem e avaliação referente à aprendizagem dos surdos. Por último, análise interpretativa do conteúdo dos relatos de experiência daqueles profissionais, enumerados sucessivamente de R1 a R16 no Quadro 3. Para tanto, apoiamos no referencial teórico construído mediante revisão bibliográfica e documental de acordo os tópicos 1 e 2 .

\section{Discussão e resultados}

O Quadro 3 explicita o conteúdo dos relatos de experiência (enumerados sucessivamente de R1 a R16) vivenciada pelos profissionais colaboradores deste estudo - P1, P2 e P3 -, em seus respectivos contextos escolares. Considerando as percepções que emanam desses enunciados, observa-se que os direitos do aluno surdo, no que tange à uma educação que atenda às reais necessidades destes, previstos no Quadro 1 da seção 2, ainda não se tornaram ações concretas. Tendo em vista o percurso histórico das lutas empreendidas e os direitos adquiridos, constata-se uma grande distância entre o que está posto nos documentos públicos do Estado brasileiro com o que temos, em termos de resultados do ensinoaprendizagem, respectivamente nos contextos institucionais dos participantes. Após apresentação do quadro de conteúdo dos relatos e suas categorias de análise método e avaliação, passamos à discussão dos resultados. 


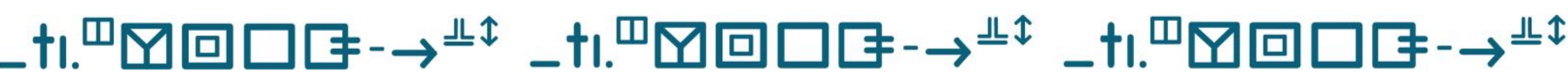

Métodos de ensino e avaliação da aprendizagem de surdos no Ensino Médio: o que dizem os profissionais de Libras-Português?

Edivaldo dos Santos Júnior • Rivadavia Porto Cavalcante et al.

\section{Quadro 3 - Relatos de experiência: métodos de ensino e avaliação} /aprendizagem de surdos

\begin{tabular}{|c|c|}
\hline & Relatos do P1 \\
\hline Método & $\begin{array}{l}\text { R1 - O Professor ditava conteúdos do livro para que os alunos copiem em seus cadernos. } \\
\text { R2 - O Professor escrevia conteúdos na lousa, sentava-se à mesa e explicava a matéria } \\
\text { enquanto os alunos copiavam. }\end{array}$ \\
\hline Avaliação & $\begin{array}{l}\text { R3 - A avaliação do surdo se dá por meio de provas e testes idênticos aos dos alunos } \\
\text { ouvintes. }\end{array}$ \\
\hline \multirow[b]{2}{*}{ Método } & Relatos do P2 \\
\hline & $\begin{array}{l}\text { R4 - Referente à metodologia de ensino na sala de aula infelizmente temos um grande } \\
\text { caminho a percorrer. Os professores ainda não vinculam o aluno ao processo de ensino e } \\
\text { aprendizagem deixando ele de lado. As metodologias visuais não são utilizadas, na maioria } \\
\text { das vezes. } \\
\text { R5 - O aluno não tem apoio de recursos imagéticos nas explicações dos professores. As } \\
\text { aulas dos professores ainda são com base somente em textos, o que não é prático para } \\
\text { facilitar o aprendizado do aluno. } \\
\text { R6 - Um professor queria que o aluno compreendesse conteúdos de textos metafóricos e } \\
\text { não havia nenhum recurso que auxiliasse o entendimento do texto. Ele pediu o aluno que } \\
\text { esperasse aula terminar já que não ia aprender nunca. }\end{array}$ \\
\hline Avaliação & $\begin{array}{l}\text { R7 - As avaliações são inteiramente textuais com questões discursivas, que na maioria das } \\
\text { vezes compromete a resposta do sujeito surdo. } \\
\text { R8 - As provas não se adaptam à condição do aluno. } \\
\text { R9 - Nós fazemos a leitura da prova com os alunos traduzindo as questões e eles dão a } \\
\text { resposta em Libras e a gente faz a transcrição daquilo que eles entendem. }\end{array}$ \\
\hline \multirow[b]{2}{*}{ Método } & Relatos do P3 \\
\hline & $\begin{array}{l}\text { R10 - Sobre metodologias de ensino vejo uma carência muito grande de formação e } \\
\text { interesse dos professores sobre a Libras. Muitos ainda não sabem lidar com esse aluno. } \\
\text { Precisam sempre de um intérprete para estar ali orientando naquilo que for necessário. } \\
\text { R11 - Aqui a carência é maior que outros estados. Até mesmo no básico do atendimento, os } \\
\text { alunos ainda não têm intérpretes, nenhum tipo de apoio. Vejo que tem um atraso ainda } \\
\text { muito grande aqui na região. } \\
\text { R12 - Às vezes colocam o intérprete sem formação nenhuma, sem conhecimento mínimo } \\
\text { para poder atuar como intérprete, uma pessoa que fez só um curso básico. Isso prejudica } \\
\text { o surdo muito mais do que auxiliando ele ali, né. } \\
\text { R13 - A escassez de metodologias voltadas para o surdo e de pesquisas são pouco } \\
\text { desenvolvidas na área. }\end{array}$ \\
\hline Avaliação & $\begin{array}{l}\text { R14 - Alguns professores fazem adaptações, realizando avaliação oral com o aluno, } \\
\text { mediados pelos intérpretes. } \\
\text { R15 - Outros professores mais tradicionais acham que a prova tem que ser daquele jeito, } \\
\text { prova escrita no papel e que tem que ter o registro. } \\
\text { R16 - Muitos professores têm dificuldade de professores em aceitar essa adaptação. }\end{array}$ \\
\hline
\end{tabular}

Fonte: Elaborado pelos autores (2021).

Descrição da imagem: Quadro 3 intitulado "Relatos de experiência: métodos de ensino e avaliação/aprendizagem de surdos". O Quadro apresenta a transcrição dos relatos de experiência gerados por meio das entrevistas com os profissionais. 


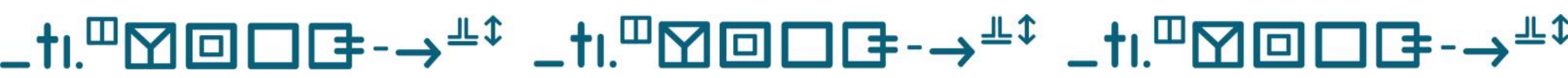

Métodos de ensino e avaliação da aprendizagem de surdos no Ensino Médio: o que dizem os profissionais de Libras-Português?

Edivaldo dos Santos Júnior • Rivadavia Porto Cavalcante et al.

Os dados do Quadro 3 apontam que os métodos de ensino e avaliação da aprendizagem dos conteúdos linguageiros nos contextos de atuação de P1, P2 e P3 não são adequados e não valorizam a cultura surda, o que amputa as possibilidades de acesso aos conhecimentos necessários ao desenvolvimento intelectual do educando surdo.

No contexto de atuação do P1, R1 e R2 nos mostram que o método de ensino/aprendizagem adotado pelo professor não leva em conta as necessidades do aluno surdo nos eventos de ensino, já que o docente valoriza em sua prática ditado oral "de conteúdos do livro". Tal falta de adequação na abordagem do docente dificulta o trabalho do intérprete. $O$ discurso deste indica que as aulas são tradicionalmente expositivas com atividades de aprendizagem baseadas em cópias de conteúdos com registro no caderno. Em decorrência disso, têm-se alunos surdos copistas dos escritos dos colegas ouvintes, configurando-se, assim, o que Freire (1987) denomina de educação depositária. Logo, o aluno surdo é visto como recipiente e não como um sujeito que tem seus direitos educacionais bilíngues garantidos legalmente, conforme disposto nos documentos públicos do Estado brasileiro (BRASIL, 2002, 2005, 2008, 2015).

Já no que tange à avaliação do aluno, o relato em R3 aponta que tal procedimento não se adéqua à sua realidade linguística. Conforme revelado nas expressões de $\mathrm{P} 1$, no contexto em questão, essa etapa do processo educacional se dá em detrimento de uma avaliação formativa e contínua, prevalecendo a obtenção de notas mediante conteúdo decorado, o que foge aos princípios de uma educação inclusiva que, nas argumentações de Quadros (2005), a dimensão avaliativa da aprendizagem daquele discente deve convergir com suas particularidades linguístico-culturais. 


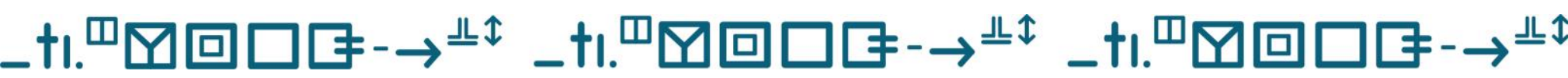

Métodos de ensino e avaliação da aprendizagem de surdos no Ensino Médio: o que dizem os profissionais de Libras-Português?

Edivaldo dos Santos Júnior • Rivadavia Porto Cavalcante et al.

As contribuições de Chevallard (2013) aqui se mostram bastante pertinentes. O autor assevera que o professor precisa transpor/mediar os saberes a serem ensinados para além dos conteúdos planejados, evitando sua reprodução e memorização apenas para o uso escolar. Tais procedimentos avaliativos, mediante provas e testes, visam tão somente mensurar o conteúdo que o aluno 'decorou', amputando sua capacidade e seus direitos de aprendizagem dos conhecimentos necessários ao seu crescimento intelectual.

Os comentários de P2 representados em R4 e, R5 explicitam que, em seu contexto de atuação, há "um grande caminho a percorrer" em termos de métodos de ensino. O profissional relata um quadro de isolamento do aluno não ouvinte que, por sua vez, diante de suas condições e limitações, depende da linguagem visual para se orientar na construção dos saberes necessários para sua participação social. Esse fato nos revela a ausência de criação de condições de aprendizagem naquele contexto educacional, já que "ensinar vai além do ato de 'transferir o conhecimento, mas criar as possibilidades' para que o aluno avance em sua produção com autonomia" (FREIRE, 1996, p. 47).

A contradição do método utilizado pelo professor reside no fato de que seus procedimentos didáticos se pautam tão "somente em textos", deixando de lado o uso das linguagens visuais, os recursos imagéticos. Logo, infere-se que o método em pauta não se aplica ao aluno surdo, atrapalhando seu entendimento nas "explicações dos professores", porém contempla o aluno ouvinte.

O relato em R6 põe em evidência que o método do professor de LP trabalha contra as necessidades específicas e a singularidade linguística do surdo, que não consegue assimilar o conteúdo dos textos metafóricos devido 


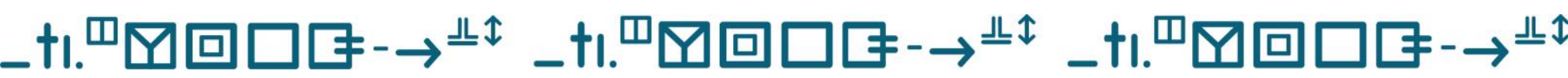

Métodos de ensino e avaliação da aprendizagem de surdos no Ensino Médio: o que dizem os profissionais de Libras-Português?

Edivaldo dos Santos Júnior • Rivadavia Porto Cavalcante et al.

à inexistência de recursos "que auxiliasse no entendimento do texto". "Ela [a professora] pediu ao aluno que esperasse a aula terminar, porque ele não ia aprender nunca". Esse enunciado revela que o método utilizado pelo docente não considera os saberes prévios e a cultura surda, bem como a natureza bilíngue desse aluno. Estudiosos (FREIRE, 1996; QUADROS, 2003, 2005; VYGOTSKY, 2011; SKLIAR, 2017) advertem que a construção da autonomia da aprendizagem de surdos se dá mediante apropriação dos signos visuoespacial, os quais são conhecimentos essenciais ao seu pleno desenvolvimento intelectual, notadamente no reconhecimento de seu direito e seu papel social na produção do saber.

Embora a Libras seja uma das línguas das comunidades surdas, por se tratar de uma língua visuo-espacial, a maioria dos professores a desconhece. Decorrente disso, seus métodos e suas aulas não se adéquam às necessidades deste público estudantil. Porém, os recursos visuais são de grande utilidade na implementação de uma transposição e adequação didática dos saberes a ensinar e a ser aprendido nos eventos de ensino (CHEVALLARD, 2000).

Quanto aos procedimentos avaliativos da aprendizagem, os relatos em $\mathrm{R} 7$ e $\mathrm{R} 8$ ratificam a abordagem unidirecional do método de ensino do docente, centrado apenas na leitura do texto escrito "com questões discursivas", sem levar em conta as limitações da capacidade de expressão em LP. Logo, constatamos que o profissional de ensino de que se trata não está preparado para trabalhar em contextos heterogêneos que demandam inclusão/inserção socioeducacional. A esse respeito, Freire (1996) orienta que o educador precisa compreender as diferenças sociais, as condições de vida e necessidades de seu público discente, o que pressupõe adequação do método avaliativo. 


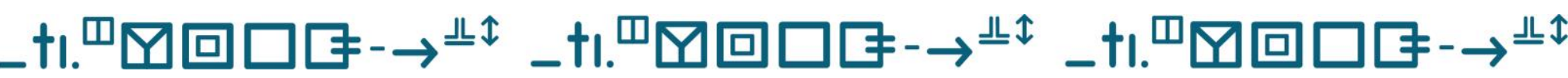

Métodos de ensino e avaliação da aprendizagem de surdos no Ensino Médio: o que dizem os profissionais de Libras-Português?

Edivaldo dos Santos Júnior • Rivadavia Porto Cavalcante et al.

processos avaliativos diferenciados para o educando surdo, levando em conta seu modus vivendi.

O relato em R10 traduz a experiência vivenciada por P3 na educação de surdos, em meio à escassez de metodologias de ensino que motivem formação e interesses dos professores pela LS, o que, consequentemente, no discurso de P3, impede tais profissionais de saberem lidar com a especificidade e limitações do público discente em pauta, aumentando a dependência por intérpretes para orientação "naquilo que for necessário" junto ao aluno. Este dado indica que a funcionalidade do método de ensino para os surdos, nesse contexto, não depende do professor, posto que ele não domina a língua daquela população estudantil, ficando a responsabilidade, portanto, a cargo do intérprete/tradutor. Neste caso, cabe, segundo Freire (1996), ao docente estar ciente de que sua atuação na prática educativa tem compromissos com a atualização contínua de sua base de conhecimento teórico e geral.

Outrossim, P3 salienta, mediante os relatos em R11 e R12, as limitações de seu contexto regional em termos de "atendimento básico" ao referido público estudantil, como a falta de intérpretes formados e de apoio aos discentes. O profissional esboça em seu discurso um cenário marcado por "um atraso ainda muito grande" em relação a outros estados brasileiros, como a ausência de profissionais habilitados que engajou pessoas na posição de intérpretes sem a devida formação. Decorrente disso, graves problemas no ensino de surdos estão prejudicando "muito mais do que auxiliando". A LDB (BRASIL, 1996, Art. 59, inciso III) abre possibilidades para que os direitos educacionais dos alunos com necessidades educacionais especiais sejam concretizados e docentes e outros profissionais atualizem seus conhecimentos didático-pedagógicos. 


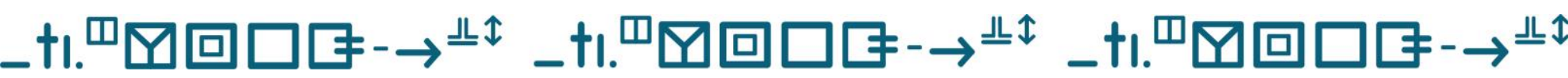

Métodos de ensino e avaliação da aprendizagem de surdos no Ensino Médio: o que dizem os profissionais de Libras-Português?

Edivaldo dos Santos Júnior • Rivadavia Porto Cavalcante et al.

Ademais, o relato em R13 expõe sobre a escassez de métodos voltados para a educação de surdos e de pesquisas no contexto regional de P3. Este dado atesta distanciamento das disposições dos documentos orientadores para a implementação dos direitos educacionais desse grupo social previstos nos documentos da Figura 1, com os reais resultados no local de ensinoaprendizagem. Sobre tal contradição desta política educacional, Vygotsky (1997) argumenta que a implementação dos métodos de ensino depende de uma reestruturação geral do sistema escolar, considerando princípios educativos sociais. Dito em outros termos, apesar da existência de leis educacionais, nem sempre elas são implementadas porque dependem de atualização no próprio sistema didático-pedagógico.

Quanto aos procedimentos avaliativos, os relatos em R14, R15 e R16 revelam que, em tais ações, alguns educadores procedem adaptações, enquanto outros não, priorizando "prova escrita em papel como registro", o que denota em seus enunciados que os docentes ainda não estão preparados para avaliar o aluno surdo, posto que têm "dificuldade de aceitar adaptações". Nesse caso, Freire nos instrui que, se o professor não pode adaptar seus saberes ao do aluno, não pode "impor-lhe seu saber como o verdadeiro" (FREIRE, 1996, p. 8), o que requer, nesse contexto, a premência de atualização da formação docente em sintonia com as reais necessidades de seu público discente.

\section{Considerações finais}

Neste artigo, investigamos e discutimos relatos de experiência vivenciada por profissionais de Libras-Português, atuantes na educação de surdos em três diferentes contextos institucionais do estado do Tocantins. O objetivo foi analisar e discutir o método de ensino e de avaliação dos saberes 


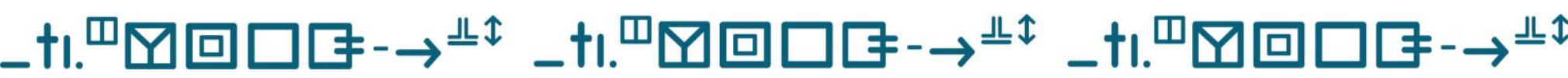

Métodos de ensino e avaliação da aprendizagem de surdos no Ensino Médio: o que dizem os profissionais de Libras-Português?

Edivaldo dos Santos Júnior • Rivadavia Porto Cavalcante et al.

de linguagem em sala de aula regular do Ensino Médio público. A base teórica, o modelo de pesquisa qualitativa e os procedimentos analíticos utilizados permitiram responder o questionamento do estudo e objetivo traçado, conforme evidenciam os dados analisados com base no Quadro 3.

Os relatos de experiência indicam disparidade e contradições das práticas de ensino e aprendizagem na educação de surdos com relação aos textos oficiais do Quadro 1. As falas de P1, P2 e P3 revelam inadequação dos métodos de ensino e avaliativos, nos quais língua e cultura do surdo são menosprezadas, prevalecendo apenas o método de leitura de texto em português. As linguagens visuais, que, por sua vez, caracterizam a língua do surdo, não integram o conjunto dos saberes necessários ao desenvolvimento do aluno surdo, percebendo este sob o ponto de vista do ouvinte, conforme os enunciados de P1 e P2. Os argumentos de P3 nos apontam que professores carecem reaprender o ensino de linguagem para além do método avaliativo unidirecional pautado na homogeneização do ser, considerando a heterogeneidade como espaço de reconhecimento das diferenças sociais.

Além disso, destacam-se nos relatos desses profissionais a falta de conhecimento dos professores de que o aluno surdo é por natureza bilíngue, possuidor de identidade, cultura e capacidade de aprendizagem diferentes dos ouvintes. Porém, tais diferenças não o tornam inferior em termos de igualdade com relação a estes devido à falta de preparação e formação de profissionais aptos na condução do processo formativo do estudante surdo, segundo os relatos de P3. Isso pressupõe, da parte do Estado brasileiro, instituições educacionais e seus agentes, segundo os aportes vygotskyanos, a premência de diálogos que minimizem o distanciamento entre tais instâncias na busca de ações para uma reestruturação do sistema 


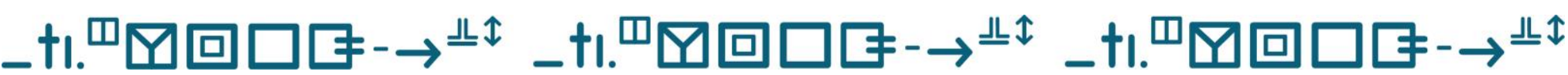

Métodos de ensino e avaliação da aprendizagem de surdos no Ensino Médio: o que dizem os profissionais de Libras-Português?

Edivaldo dos Santos Júnior • Rivadavia Porto Cavalcante et al.

educacional, a adaptação dos métodos e saberes a ser ensinados ao surdo, tendo como trilha o caminho do bilinguismo.

Não cabe aqui concluir a problemática discutida neste trabalho, e sim fazer apontamentos para mais pesquisas sobre adequação/adaptação dos saberes escolares na educação do surdo, considerando suas necessidades e a sua singularidade linguístico-cultural, principalmente estudos interventivos, no campo da didática, com vistas à implementação de seus direitos. Entendemos, a partir do trabalho realizado, que muito ainda precisa ser feito nesta direção.

\section{Referências}

BARDIN, L. Análise de conteúdo. São Paulo: Edições 70, 2011.

BRASIL. Constituição (1988). Constituição da República Federativa do Brasil. Brasília, DF: Senado Federal: Centro Gráfico, 1988. Disponível em: http://www.planalto.gov.br/ccivil_03/constituicao/constituicao.htm, Acesso em 09 de abr. de 2020.

BRASIL. Lei 9.394/96, de 20 de dezembro de 1996. Estabelece as diretrizes e bases da educação nacional. Diário Oficial da República Federativa do Brasil, Brasília, DF, 31 de dez.1996. Disponível em: http://www.planalto.gov.br/ccivil_03/leis/19394.htm Acesso em 03 de out. de 2019.

BRASIL. Ministério da Educação. Conselho Nacional de Educação. Resolução CNE/CEB no. 2, de 11 de setembro de 2001. Diretrizes Nacionais para a Educação Especial na Educação Básica. Diário Oficial da República Federativa do Brasil, Brasília, DF, 14. set. 2001. Disponível em: https://www.gov.br/mec/pt-br/publicacoes-secretarias/semesp/diretrizes- 


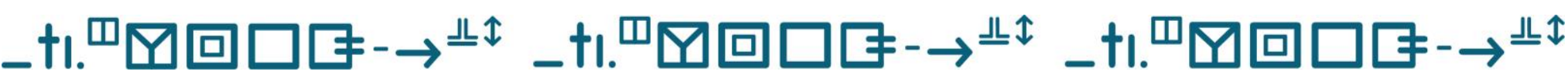

Métodos de ensino e avaliação da aprendizagem de surdos no Ensino Médio: o que dizem os profissionais de Libras-Português?

Edivaldo dos Santos Júnior • Rivadavia Porto Cavalcante et al.

nacionais-para-a-educacao-especial-na-educacao-basica Acesso em 20 de maio 2020.

BRASIL. Lei n ${ }^{\circ}$ 10.436, de 24 de abril de 2002. Dispõe sobre a Língua Brasileira de Sinais - Libras e dá outras providências. Brasília: DF, abr. 2002. Disponível em: http://www.planalto.gov.br/ccivil_03/leis/2002//10436.htm Acesso em 03 de out. de 2019.

BRASIL. Decreto $\mathbf{n}^{\circ}$ 5.626, de 22 de dezembro de 2005. Regulamenta a Lei $\mathrm{n}^{\circ}$ 10.436, de 24 de abril de 2002, que dispõe sobre a Língua Brasileira de Sinais - Libras, e o art. 18 da Lei no 10.098 de 19 de dezembro de 2000. Brasília: DF, dez. 2005. Disponível em: http://www.planalto.gov.br/ccivil_03/_Ato20042006/2005/Decreto/D5626.htm Acesso em 03 de out. de 2019.

BRASIL. Ministério da Educação. Política Nacional de Educação Especial na perspectiva da Educação Inclusiva. Brasília: DF. MEC; SEEP, 2008. Disponível em: http://portal.mec.gov.br/arquivos/pdf/politicaeducespecial.pdf Acesso em 6 de jun. 2020.

BRASIL. Lei $\mathbf{n}^{\circ}$ 12.319, de 1 de setembro de 2010. Regulamenta a profissão de Tradutor e Intérprete da Língua Brasileira de Sinais - LIBRAS. Brasília: DF, set. 2010. Disponível em: http://www.planalto.gov.br/ccivil_03/_Ato20072010/2010/Lei/L12319.htm Acesso em 20 de abr. de 2020.

BRASIL. Lei № 13.146, de 6 de julho de 2015. Institui a Lei Brasileira de Inclusão da Pessoa com Deficiência (Estatuto da Pessoa com Deficiência). Brasília: DF. jun. 2015. Disponível em: http://www.planalto.gov.br/ccivil_03/_ato2015-2018/2015/lei/113146.htm Acesso em 14 de maio de 2020. 


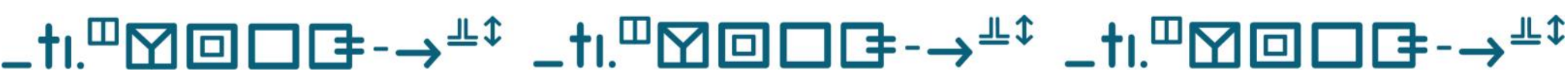

Métodos de ensino e avaliação da aprendizagem de surdos no Ensino Médio: o que dizem os profissionais de Libras-Português?

Edivaldo dos Santos Júnior • Rivadavia Porto Cavalcante et al.

BRASIL. Saeb 2017 revela que apenas 1,6\% dos estudantes brasileiros do Ensino Médio demonstraram níveis de aprendizagem considerados adequados em Língua Portuguesa. Brasília: DF, 2017. Disponível em: http://portal.inep.gov.br/artigo/-

/asset_publisher/B4AQV9zFY7Bv/content/saeb-2017-revela-que-apenas-1-6dos-estudantes-brasileiros-do-ensino-medio-demonstraram-niveis-deaprendizagem-considerados-adequados-em-lingua-portug/21206 Acesso em 20 de abr. de 2020

CHEVALLARD, Y. Sobre a teoria da transposição didática: algumas considerações introdutórias. Trad. Cleonice Puggian. Revista de Educação,

Ciências e Matemática, v.3 n.2 mai/ago 2013. Disponível em: http://publicacoes.unigranrio.edu.br/index.php/recm/article/view/2338 Acesso em 20 de Abr. 2020.

CHEVALLARD, Y. La transposición didáctica. Del saber sabio al saber enseñado. Trad. Cláudia Gilman. $3^{\text {a }}$ ed. Buenos Aires: Aique, 2000.

FELIPE, T. A. Libras em contexto. $7^{\text {a }}$ ed. Rio de Janeiro: LIBRAS Editora Gráfica, 2006.

FLICK, U. Métodos de Pesquisa: introdução à pesquisa qualitativa. $3^{a}$ Ed. Porto Alegre: Artmed, 2009.

FREIRE, P. Pedagogia do oprimido. 17a . ed. Rio de Janeiro: Paz e Terra, 1987. FREIRE, P. Pedagogia da autonomia. 25a ed. São Paulo: Paz e Terra, 1996.

GESSER, A. Do patológico ao cultural na surdez: para além de um e de outro ou para uma reflexão crítica dos paradigmas. Trab. Ling. Aplic, Campinas, 47(1) Jan./Jun. 2008.2 Disponível em: https://www.scielo.br/pdf/tla/v47n1/v47n1a12.pdf Acesso em 29 de maio de 2020. 


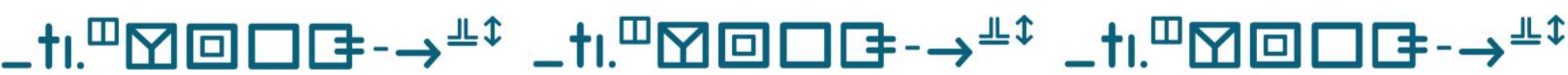

Métodos de ensino e avaliação da aprendizagem de surdos no Ensino Médio: o que dizem os profissionais de Libras-Português?

Edivaldo dos Santos Júnior • Rivadavia Porto Cavalcante et al.

GIL, A. C. Métodos e técnicas de pesquisa social. $6^{\mathrm{a}}$ ed. São Paulo: Atlas, 2008.

KAUARK, F.; MANHÃES, F. C.; MEDEIROS, C. H. Metodologia da pesquisa: guia prático. Itabuna: Via Litterarum, 2010. Disponível em: http://www.pgcl.uenf.br/arquivos/livrodemetodologiadapesquisa2010_0111 20181549.pdf Acesso em 11 de junho de 2020.

MALLMANN, F. M. et al. A Inclusão do Aluno Surdo no Ensino Médio e Ensino Profissionalizante: um Olhar para os Discursos dos Educadores. Rev. Bras. Ed. Esp., Marília, v. 20, n. 1, p. 131-146, Jan.-Mar., 2014. Disponível em: https://www.scielo.br/pdf/rbee/v20n1/a10v20n1.pdf Acesso em 01 de jun. 2020.

MANACORDA, M. A. Marx e a pedagogia moderna. Campinas, SP: Editora Alínea, 2007.

ONU. Declaração Universal dos Direitos Humanos. 1948. Disponível em: https://www.ohchr.org/EN/UDHR/Pages/Language.aspx?LangID=por Acesso em 09 de jun. 2020.

POWER, S. O detalhe e o macrocontexto: o uso da teoria centrada no Estado para explicar práticas e políticas educacionais. In: BALL, S. J.; MAINARDES, J. (Orgs). Políticas Educacionais: questões e dilemas. São Paulo: Cortez, 2011. p. 54-77.

QUADROS, R. M. O 'Bl' em bilinguismo na educação de surdos. In: FERNANDES, Eulália (Org.). Surdez e bilinguismo. Porto Alegre: Mediação, 2005 p. 26-36.

QUADROS, R. M. Situando as Diferenças Implicadas na Educação de Surdos: Inclusão/exclusão. Revista Ponto de Vista. UFSC, N4, 2003. Não paginado. Disponível em: 


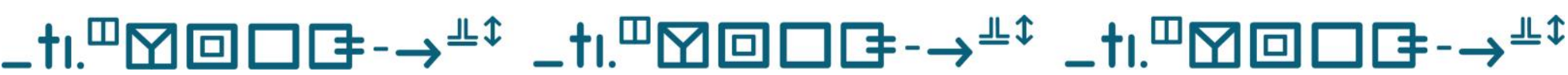

Métodos de ensino e avaliação da aprendizagem de surdos no Ensino Médio: o que dizem os profissionais de Libras-Português?

Edivaldo dos Santos Júnior • Rivadavia Porto Cavalcante et al.

https://periodicos.ufsc.br/index.php/pontodevista/article/viewFile/1246/385 0. Acesso em: 25 de jul.2020.

ROSA, W.; LOCATELLI, A. Produtos educacionais: diálogo entre universidade e escola. Ensino de Ciências e Tecnologia em Revista, v. 8, n. 2. jul./ago. 2018.

Disponível

em: http://srvapp2s.urisan.tche.br/seer/index.php/encitec/article/view/2716/0 Acesso em 10 de abr. 2020.

SANTOS, A. D. W.; BORDAS, M. A. Garcia. A educação do surdo e a pedagogia freiriana. In: V CONGRESSO BRASILEIRO MULTIDISCILINAR DE EDUCAÇÃO ESPECIAL, 2009, Londrina. Anais do V congresso brasileiro multidisciplinar de educação especial. Londrina, 2009. Disponível em: http://www.uel.br/eventos/congressomultidisciplinar/pages/arquivos/anais/ 2009/009.pdf\# Acesso em 15 de jun. 2020.

SANTOS, W. F.; MENEZES, M. B. A Transposição Didática interna em uma sala de aula inclusiva: O caso do ensino para surdos sobre o conjunto dos números naturais. Educ. Matem. Pesq., São Paulo, v.21, n.5, pp. 102-114, 2019. Disponível em: http://revistas.pucsp.br/emp/article/view/45581 Acesso em 15 de abr. 2020.

SILVA, A. C. A representação social da surdez: entre o mundo acadêmico e o cotidiano escolar. In: FERNANDES, E. (Org.). Surdez e bilinguismo. Porto Alegre: Mediação, 2005 p. 37- 49.

SILVA, R. A. C. Um olhar sobre o surdo na nova Base Nacional Comum Curricular no Brasil. Revista Virtual de Cultura Surda. Edição Nº 23. Maio de 2018. Disponível em: http://editora-araraazul.com.br/site/admin/ckfinder/userfiles/files/6\%C2\%BA\%20Artigo\%20da\% 


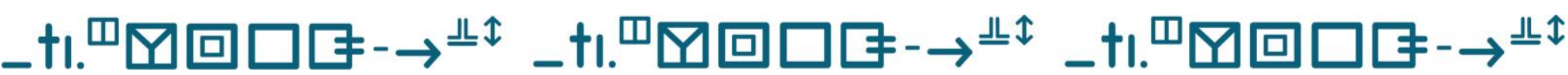

Métodos de ensino e avaliação da aprendizagem de surdos no Ensino Médio: o que dizem os profissionais de Libras-Português?

Edivaldo dos Santos Júnior • Rivadavia Porto Cavalcante et al.

20Revista\%2023\%20de\%20CAMARA\%20SILVA.pdf Acesso em 19 de Nov. 2019.

SKLIAR, C. As diferenças e as pessoas surdas. Revista Fórum: Rio de Janeiro. $n^{\circ} \quad 35 . \quad 17-24 . \quad$ jan-jun 2017. Disponível em: http://www.ines.gov.br/seer/index.php/forumbilingue/issue/viewlssue/21/24 Acesso em 29 de fev. 2020.

SOARES, M. Alfabetização e Letramento: caminhos e descaminhos. In: Universidade Estadual Paulista. UNESP. Pró-Reitoria de Graduação. Caderno de Formação: Formação de professores. Didática dos Conteúdos. São Paulo: Cultura Acadêmica, 2011. v.2 193p (curso de Pedagogia), p. 96-100. Disponível também em: Revista Pátio-Revista Pedagógica de 29 de fevereiro de 2004. Ed. Artmed.

UNESCO. Declaração mundial sobre educação para todos. 1990. Resultado da Conferência Mundial sobre Educação para Todos - satisfação das necessidades básicas de aprendizagem. Jomtien, Tailândia, 5 a 9 de março de 1990. Disponível em: https://www.unicef.org/brazil/declaracao-mundialsobre-educacao-para-todos-conferencia-de-jomtien-1990 Acesso em 02 de jun. 2020.

UNESCO. Coordenadoria Nacional para a Integração da Pessoa Portadora de Deficiência (CORDE). Declaração de Salamanca de princípios, política e prática para as necessidades educativas especiais. Brasília: CORDE, 1994.

Disponível em: http://portal.mec.gov.br/seesp/arquivos/pdf/salamanca.pdf Acesso em 04 de abr. 2020.

VYGOTSKY, L. S. Pensamento e linguagem. São Paulo: Martins Fontes, 1993. VYGOTSKI, L. S. Obras Escogidas. v. 5. Fundamentos de Defectología. Madrid: Visor, 1997. 


\section{_tı.}

Métodos de ensino e avaliação da aprendizagem de surdos no Ensino Médio: o que dizem os profissionais de Libras-Português?

Edivaldo dos Santos Júnior • Rivadavia Porto Cavalcante et al.

VYGOTSKY, L. S. A defectologia e o estudo do desenvolvimento e da educação da criança anormal. Educação e Pesquisa, São Paulo, v. 37, n. 4, p. 861-870, dez. 2011. Disponível em: http://www.scielo.br/pdf/ep/v37n4/a12v37n4.pdf Acesso em 22 de abr. 2020.

YIN, R. K. Estudo de caso: planejamento e métodos. 4. ed. Porto Alegre: Bookman, 2010.

\section{Publisher}

UNIVERSIDADE FEDERAL DE GOIÁS. CURSOS DE LETRAS: LIBRAS E DE LETRAS: TRADUÇÃO E INTERPRETAÇÃO EM LIBRAS/PORTUGUÊS DA Faculdade de Letras/UfG. PublicaÇÃo nO PORTAL De Periódicos UFG. AS IDEIAS EXPRESSADAS NESTE ARTIGO SÃO DE RESPONSABILIDADE DE SEUS AUTORES, NÃO REPRESENTANDO, NECESSARIAMENTE, A OPINIÃO DOS EDITORES OU DA UNIVERSIDADE. 